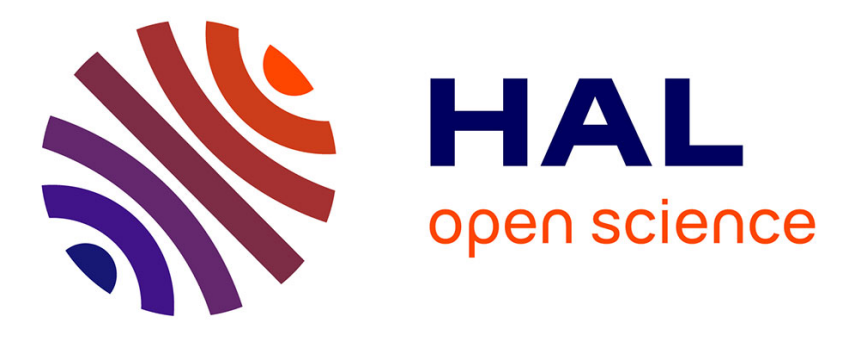

\title{
Seed mortality in the soil is related to seed coat thickness
}

Antoine Gardarin, Carolyne Dürr, Maria R Mannino, Hugues Busset, Nathalie Colbach

\section{- To cite this version:}

Antoine Gardarin, Carolyne Dürr, Maria R Mannino, Hugues Busset, Nathalie Colbach. Seed mortality in the soil is related to seed coat thickness. Seed Science Research, 2010, 20, pp.243 - 256. $10.1017 / \mathrm{s} 0960258510000255$. hal-03335838

\section{HAL Id: hal-03335838}

https://hal-agroparistech.archives-ouvertes.fr/hal-03335838

Submitted on 13 Sep 2021

HAL is a multi-disciplinary open access archive for the deposit and dissemination of scientific research documents, whether they are published or not. The documents may come from teaching and research institutions in France or abroad, or from public or private research centers.
L'archive ouverte pluridisciplinaire HAL, est destinée au dépôt et à la diffusion de documents scientifiques de niveau recherche, publiés ou non, émanant des établissements d'enseignement et de recherche français ou étrangers, des laboratoires publics ou privés. 


\title{
Seed mortality in the soil is related to seed coat thickness
}

\author{
Antoine Gardarin ${ }^{1}$, Carolyne Dürr ${ }^{2}$, Maria R. Mannino ${ }^{3}$, \\ Hugues Busset ${ }^{1}$ and Nathalie Colbach ${ }^{1}$
}

Seed Science Research (2010) 20: 243-256 - doi:10.1017/S0960258510000255

${ }^{1}$ INRA, AgroSup Dijon, UB, UMR 1210 Biologie et Gestion des Adventices, 21000 Dijon, France

2 INRA, UMR 1191 Physiologie Moléculaire des Semences, 49000 Angers, France

${ }^{3}$ GEVES - Station Nationale d'Essai de Semences, 49000 Beaucouzé, France

Correspondence: antoine.gardarin@inrae.fr

\section{Summary}

Models that quantify the effects of cropping systems on weed dynamics are useful tools for testing innovative cropping systems. In these models, seed mortality in the soil is a key parameter to account for the cumulated effect of cropping systems over time via the soil seed bank. Since seed mortality is difficult to measure, our objective was to develop a method to estimate it from easily accessible information. Seeds of 13 weed species were buried $30 \mathrm{~cm}$ deep in fields and were recovered regularly for two years to measure their viability. Seed mass, dimensions, shape, and protein and lipid contents as well as coat thickness were measured. To estimate seed mortality of species not included in the study, we searched for relationships between mortality rates and seed traits. Seed viability mainly decreased during the second year of burial, with mortality rates ranging from 0.01 to 0.63 seeds $\cdot \operatorname{seeds}^{-1} \cdot y^{2} \mathrm{rr}^{-1}$, depending on the species. Seed mortality decreased with increasing seed coat thickness. No correlation was found with other measured traits or with seed persistence data in the literature. These results were confirmed when the effects of phylogenetic relatedness with phylogenetically independent contrasts were included. The thickness of the seed coat, which varied between 17 and $231 \mu \mathrm{m}$ over the range of species studied, can protect the seed from external attacks in the soil and slow down seed decay. This trait can be easily measured via Xray images and could be used to estimate the seed mortality rate for a wider range of species.

Keywords: lipid content; seed coat; seed mass; seed mortality; seed shape; seed trait; weed. 


\section{Introduction}

Weed control in arable fields mainly relies on herbicide applications. Because of their environmental consequences (e.g. water pollution, loss of biodiversity), it is now necessary to limit the use of herbicides by taking into account all the cropping system components. Most weed seeds survive for several years in the soil and form persistent seed banks (Burnside et al., 1996; Conn et al., 2006; Murdoch and Ellis, 2000). Depending on their longevity in the soil, seeds can germinate several years after their production and species can thus reappear in a field from which they have been absent for several years. Consequently, weed control must not only focus on yield loss at an annual scale but be reasoned over several years to be efficient in both the short and long-term (Clements et al., 1994).

Modelling is an essential tool to design and evaluate integrated cropping systems for weed management because of the multi-year scale of weed management and because of the wide variation in agricultural practices (rotations, tillage, etc.) and the complexity of their interactions (Holst et al., 2007). One of the most complete models of cropping system effects was developed for Alopecurus myosuroides Huds. (ALOMYSYS, Colbach et al., 2007), and we are now working on a multi-specific version. Among the weed life-cycle processes, seed bank losses due to in situ seed mortality in the soil play a crucial role in long-term dynamics in these models. These mortality processes must be assessed and modelled independently from weed seed germination because the latter is influenced differently by cropping system components (effect of seed depth, date of tillage, etc., Boyd and Van Acker, 2003). Seed mortality results from seed embryo aging caused by physiological or chemical damage (Priestley, 1986), pathogen attacks by bacteria or fungi (Chee-Sanford et al., 2006; Wagner and Mitschunas, 2008), or seed predation by vertebrates or invertebrates (Hulme, 1998). Here, we focused on the two first causes as they are responsible for major seed loss processes in deeply buried seeds (Westerman et al., 2006) which are frequent in European cropping systems mainly based on ploughing. Numerous studies have analysed weed seed longevity or persistence in fields (Burnside et al., 1996; Egley and Williams, 1990), and results for more than a thousand species are summarized in a database (Thompson et al., 1997). However, the majority of data in the literature characterizes the persistence of seed banks, without distinguishing in situ seed mortality (seed aging, pathogen attacks) from losses due to seed germination. Moreover, in some studies, seed viability after recovery from burial is measured only through germination tests, and dormant seeds are often counted as non-viable seeds (e.g. Burnside et al., 1996; Roberts and Boddrell, 1983). Results on seed bank persistence in the literature are therefore difficult to extrapolate to different cropping systems.

As a result, the seed mortality parameter remains to be estimated for a large number of species. However, it is not feasible to study every species experimentally. Our objective was thus to search for generic relationships between in situ seed mortality and easily measured traits (Weiher et al., 1999) that characterize the species, by studying species with contrasted traits as proposed by Keddy (1992). According to Violle et al. (2007), a trait is any morphological, physiological or phenological feature that is measurable at the individual level. Seed persistence has thus been correlated with seed mass and shape (Thompson et al., 1993), and seed coat thickness (Davis et al., 2008). Small spherical seeds, which penetrate the soil more easily, often display higher persistence, probably because their increased burial depth helps delay their germination and thus decreases short term seed loss. Seed mortality might be related to the composition of the seed coat, which forms a physical and chemical barrier to preserve the seed and the embryo from parasite attacks as well as temperature and water fluctuations (Mohamed-Yasseen et al., 1994). Relationships between seed mortality and seed composition have also been analyzed in the literature. Lipid-rich seeds were thus expected to have a low survival rate because of lipid peroxidation reactions which contribute 
to the production of free radicals and thus to seed ageing (Corbineau et al., 2002). However, seed half-life was not clearly correlated with either seed composition (lipids, proteins and carbohydrates, Ponquett et al., 1992; Priestley, 1986), or phenolic compounds, which are expected to protect the seed from oxidation (Davis et al., 2008; Hendry et al., 1994).

The aim of our study was to search for functional relationships between in situ weed seed mortality and easy-to-measure seed traits (mass, shape, dimensions, composition). Data analyses accounted for the phylogenetic relatedness between the species studied. We chose species with contrasting seed masses, shapes, types of reserves and representative of the weed flora found in north-western European cropping systems. Seeds were buried in the soil and recovered sufficiently frequently to detect a possible seasonal pattern of in situ seed mortality, as previously observed for a weedy form of Beta vulgaris (Sester et al., 2006). In addition, we looked at possible correlations between in situ seed mortality and seed persistence synthesized for a large range of species by Thompson et al. (1997), in order to take advantage of this large database. Data in the literature on seed mortality, measured in similar conditions to our protocol, were used to increase the range of species we studied to search for correlations with seed traits.

\section{Material and methods}

\section{Seed burial and recovery}

Experiments consisted in burying seed bags and then excavating them every two or six months over a period of two years to analyse seed viability. Seeds of 13 weeds (table 1) commonly encountered in north-western Europe in fields under intensive cropping systems, and contrasted in their seed mass, shape and composition were collected at full maturity in 2006 in fields near Dijon $\left(47.317^{\circ} \mathrm{N}, 5.017^{\circ} \mathrm{E}, 220 \mathrm{~m}\right.$ asl.) in Burgundy, France. Immediately after collection, samples of 100 seeds were placed in nylon (Tergal) bags (mesh size $400 \mu \mathrm{m}$ ). For large seeds, $100 \mathrm{~g}$ of field soil (15\% moisture content) were added to prevent direct contact between the seeds (table 1). The soil (0.35 clay, 0.57 silt and $0.08 \mathrm{~g}^{-\mathrm{g}^{-1}}$ sand) was collected from a field at the burial site (see below). The site was not managed during the burial experiment and weeds that emerged were not removed to ensure a permanent plant canopy and to avoid soil cracks. Seed bags were placed at the bottom of open-work baskets, with three bags per species and basket. The baskets were filled with soil and buried at a depth of approximately $30 \mathrm{~cm}$ in a field at the INRA experimental station at Dijon-Époisses (France) in 2006. The depth of $30 \mathrm{~cm}$ was chosen to minimize seed loss by germination during the experiment. Every two months over the next two years, two baskets (i.e. a total of six bags) of five species were randomly excavated. For the other nine weeds, one basket was excavated approximately every six months over the next two years. When seeds were mixed with soil in the bags, the seeds were removed from the soil one by one with tweezers and the remaining soil was sieved to recover any remaining seeds.

Germination tests were carried out before burial and then at each recovery date. Seeds were set to germinate on an imbibed filter paper in the light and at constant temperatures ranging from 15 to $25{ }^{\circ} \mathrm{C}$ depending on the species for at least one month, until no more germination occurred. Temperature conditions were chosen to be optimal for each species (Lonchamp and Gora, 1980; Montégut, 1975; Webster, 1979). The germination of dormant seeds was stimulated with gibberellins or stratification, depending on the species requirements (Lonchamp and Gora, 1980; Webster, 1979). Finally, any remaining ungerminated seeds were dissected under a microscope, and firm white embryos were considered as viable (Sawma and Mohler, 2002). The percentage of viable seeds was calculated relative to the number of viable seeds initially buried. A linear (eq. 1) or a broken-stick linear model (eq. 2) was fitted to the proportion of viable seeds of each 
species against time (with 3 or 6 repetitions per date), starting with the initial viability tests, using respectively PROC GLM and PROC NLIN routines in SAS (SAS Institute, Cary, North Carolina, USA, 1999):

$$
\begin{array}{ll}
V_{s}(t)=1-D^{-} C_{s} \cdot t+\text { error } & \\
V_{s}(t)=1-D E C_{1 s} \cdot t+\text { error } & \text { if } t \leq 1 \\
V_{s}(t)=\left(1-D E C_{1 s}\right) \cdot 1-D E C_{2 s} \cdot(t-1)+\text { error } & \text { if } t>1
\end{array}
$$

$V_{s}(t)$ is the proportion (in seeds $\cdot \operatorname{seeds}^{-1}$ ) of viable seeds of the species $s$ at time $t$ (in years), i.e. the time since burial in years, $\mathrm{DEC}_{\mathrm{s}}, \mathrm{DEC}_{1 \mathrm{~s}}$ and $\mathrm{DEC}_{2 \mathrm{~s}}$ are the seed mortality rates (in seeds $\cdot$ seeds $^{-1} \cdot$ year $\left.^{-1}\right)$ for the whole period, the first and the second year of the experiment, respectively. $\mathrm{R}^{2}$ were calculated as 1 - (sum of error squares)/(total corrected sum of squares)

Table 1. Species studied and experimental conditions for the seed burial experiment. Samples of 100 seeds of each species were placed into nylon bags, with or without soil depending on the species. Seed bags were placed at the bottom of open-work baskets buried in a field at the INRA

\begin{tabular}{|c|c|c|c|c|c|}
\hline \multirow{2}{*}{ Species $^{\dagger}$} & \multirow{2}{*}{$\begin{array}{l}\text { Presence of } \\
\text { soil }(100 \mathrm{~g}) \\
\text { in the bags }\end{array}$} & \multirow{2}{*}{ Burial date } & \multirow{2}{*}{$\begin{array}{l}\text { Periodicity } \\
\text { of seed } \\
\text { recovery }\end{array}$} & \multicolumn{2}{|c|}{$\begin{array}{c}\text { Recovery rates } \\
\text { (\% of buried seeds) }\end{array}$} \\
\hline & & & & $\begin{array}{l}\text { At the start } \\
\text { of the trial }\end{array}$ & $\begin{array}{l}\text { At the end } \\
\text { of the trial }\end{array}$ \\
\hline Amaranthus hybridus L. & No & 13 September 2006 & 2 months & 100 & 60 \\
\hline Ambrosia artemisiifolia $\mathrm{L}$. & No & 11 October 2006 & 6 months & 98 & 98 \\
\hline Avena fatua $\mathrm{L}$. & Yes & 4 July 2006 & 6 months & 100 & 90 \\
\hline Capsella bursa-pastoris Medik. & Yes & 16 June 2006 & 2 months & 100 & 35 \\
\hline Chenopodium album $\mathrm{L}$. & No & 18 September 2006 & 6 months & 98 & 98 \\
\hline Digitaria sanguinalis Scop. & No & 11 October 2006 & 6 months & 100 & 22 \\
\hline Echinochloa crus-galli Beauv. & No & 1 August 2006 & 6 months & 100 & 99 \\
\hline Fallopia convolvulus Loeve & Yes & 27 September 2006 & 6 months & 100 & 98 \\
\hline Galium aparine $\mathrm{L}$. & Yes & 18 July 2006 & 2 months & 100 & 53 \\
\hline Matricaria perforata Mérat & No & 18 July 2006 & 2 months & 100 & 91 \\
\hline Papaver rhoeas $\mathrm{L}$. & No & 4 July 2006 & 6 months & 98 & 88 \\
\hline Polygonum aviculare L. & No & 2 October 2006 & 6 months & 92 & 98 \\
\hline Polygonum lapathifolium L. & Yes & 27 September 2006 & 2 months & 100 & 96 \\
\hline
\end{tabular}
experimental station of Dijon-Époisses, (France), at a seed burial depth of $30 \mathrm{~cm}$. Three and six bags were excavated every six and two months, respectively.

$\dagger$ The nomenclature follows the nomenclatural database of French flora (Kerguélen and Bock, 2009). 


\section{Measurement of seed traits}

Seed traits were measured on the same seed lots as those buried in the soil. The seed dry mass of each species was measured individually on 100 seeds dried at $80{ }^{\circ} \mathrm{C}$ for 48 hours. Images of 100 seeds were taken with a camera (pixel size comprised between 2.2 and $4.2 \mu \mathrm{m}$ according to the species) and seed area, in two dimensions, was then individually determined by image analysis (Majumdar and Jayas, 2000; Muracciole et al., 2007). For each species, a seed shape index IndVar was computed, as the variance of the relative seed dimensions (Thompson et al., 1993):

$$
\operatorname{IndVar}_{s}=\left(\frac{L_{s}-\operatorname{mean}\left(L_{s}, w_{s}, h_{s}\right)}{\max \left(L_{s}, w_{s}, h_{s}\right)}\right)^{2}+\left(\frac{w_{s}-\text { mean }\left(L_{s}, w_{s}, h_{s}\right)}{\max \left(L_{s}, w_{s}, h_{s}\right)}\right)^{2}+\left(\frac{h_{s}-\operatorname{mean}\left(L_{s}, w_{s}, h_{s}\right)}{\max \left(L_{s}, w_{s}, h_{s}\right)}\right)^{2}
$$

$\mathrm{L}_{\mathrm{s}}, \mathrm{w}_{\mathrm{s}}$ and $\mathrm{h}_{\mathrm{s}}$ are the seed length, width and height $(\mathrm{mm})$, respectively; mean $\left(\mathrm{L}_{\mathrm{s}}, \mathrm{w}_{\mathrm{s}}, \mathrm{h}_{\mathrm{s}}\right)$ and $\max \left(\mathrm{L}_{\mathrm{s}}, \mathrm{w}_{\mathrm{s}}, \mathrm{h}_{\mathrm{s}}\right)$ are the mean and maximal values of these three measurements. The seed shape index is close to zero for spherical seeds and increases for elongated or flattened seeds.

For seed composition analyses, outer structures of Poaceae seeds were removed (glumes, lemma and palea of Avena fatua and Alopecurus myosuroides, glumes of Echinochloa crus-galli). Dispersules of other species were kept intact. Seeds were dried at $80{ }^{\circ} \mathrm{C}$ for 48 hours, and two 250 -mg samples of seeds were taken from each species. Seeds were milled to a fine powder and stored at $-17{ }^{\circ} \mathrm{C}$ until further analysis. Nitrogen content was measured by the Dumas procedure (Hansen, 1989) and was multiplied by 6.25 (Mariotti et al., 2008 ) to estimate seed protein content. Lipid content was determined, following Jensen et al. (1972), by dissolving seed oil in hexane:isopropanol (3:2 v/v), centrifuging and collecting the supernatant, then evaporating the solvent with a rotary evaporator. The oil remaining in the tube was then weighed.

One hundred seeds (full dispersules) of each species were exposed to X-rays at a radiation intensity ranging from 17 to $30 \mathrm{kV}$ for five to 12 seconds (Faxitron MX-20 cabinet X-ray system) depending on the species, in order to optimize visualization of the seed coat. The thickness of the seed coat, including the tegument, the fruit coat (pericarp) and possibly the remnants of floral pieces, was then measured individually on X-ray images using image analysis software (ImageJ, Rasband, 2009). The resolution ranged between $9 \mu \mathrm{m}$ for small and $20 \mu \mathrm{m}$ for large seeded-species.

Some missing values on seed traits were completed with data from the literature. This was the case for the seed lipid and protein contents of a few species. As shown by the different measurements made by Jones and Earle (1966), Barclay and Earle (1974) and Earle and Jones (1962), these traits are relatively constant among seed lots of each species. Seed length, width and height can vary among seeds of a given species, but they were only used to calculate the seed shape index, which is less variable than the dimensions.

\section{Seed mortality and persistence estimated from the literature}

Seed mortality data $\left(\mathrm{DEC}_{\text {lit }}\right)$ were taken from multi-annual experiments found in the literature. The aim was to compare them to the mortality rates measured in the present study, in order to check their consistency and to increase the range of analysed species to search for correlations with traits. Data were only taken from studies where a known quantity of seeds was buried at a depth of more than $5 \mathrm{~cm}$ in undisturbed soil to minimize seed losses through germination. In addition, the large database of Thompson et al. (1997) was used to compute a seed persistence index to test whether this index could be used to predict seed mortality. The longevity index developed by Bekker et al. (1998) was not satisfactory because it was identical (i.e. 1) for most 
of the species studied here. The following seed persistence index was preferred because it better distinguished species according to their persistence:

$$
\text { Seed persistence index } \mathrm{s}_{\mathrm{s}}=\frac{\left(1 \cdot \mathrm{T}_{\mathrm{s}}\right)+\left(2 \cdot \mathrm{ST}_{\mathrm{s}}\right)+\left(3 \cdot \mathrm{LT}_{\mathrm{s}}\right)}{\text { total number of references }}
$$

$\mathrm{T}_{\mathrm{s}}, \mathrm{ST}_{\mathrm{s}}$ and $\mathrm{LT}_{\mathrm{s}}$ are the number of studies reporting a transient $(<1$ year), short-term persistent (between 1 and 5 years) and long-term persistent (more than 5 years) seed bank for the species $s$, respectively.

\section{Predicting seed mortality from seed traits or from the literature}

The correlation of the seed mortality rates measured here with mortality rates from the literature $\left(\mathrm{DEC}_{\text {lit s }}\right.$ ) was studied by linear regressions, using PROC GLM in SAS (SAS Institute, Cary, North Carolina, USA, 1999):

$$
\begin{aligned}
& \mathrm{DEC}_{\mathrm{s}} \text { or } \mathrm{DEC}_{1 \mathrm{~s}} \text { or } \mathrm{DEC}_{2 \mathrm{~s}}=\text { intercept }+\delta \cdot \mathrm{DEC}_{\text {lit s }}+\text { soil presence effect } \\
& +\alpha_{\text {soil presence }} \cdot \mathrm{DEC}_{\text {lit s }}+\text { error }
\end{aligned}
$$

The effect of the presence of soil was included in the model to test whether the addition of soil in the seed bags had an influence on the measured seed mortality rates. $\delta$ and $\alpha_{\text {soil presence }}$ are regression coefficients (year ${ }^{-1}$ year), with $\alpha_{\text {soil presence }}$ taking different values in the presence or absence of soil in the seed bag.

Relationships were then studied between the seed mortality parameters $\left(\mathrm{DEC}_{\mathrm{s}}, \mathrm{DEC}_{1 \mathrm{~s}}\right.$ and $\mathrm{DEC}_{2 \mathrm{~s}}$ ) measured experimentally or estimated from the literature for five additional species on one hand, and seed traits and the seed persistence index on the other hand. Mortality rates based on the literature (i.e. for Alopecurus myosuroides, Arabidopsis thaliana, Datura stramonium, Geranium dissectum and Stellaria media, see table 2) were re-estimated with equation [5] to account for possible experimental differences, instead of using the actual rates given in the original papers.

Analyses were carried out with raw data or $\log _{n}$-transformed variables. In the latter case, the linear model is equivalent to a multiplicative model, which better accounts for multiplicative interactions between factors. Multiple regressions (including all explanatory variables) were preferred to a series of successive single regressions because multiple regressions enable the detection of minor effects which are usually hidden by major effects in single regressions. Manual backward stepwise regressions were performed using proc GLM routine and type III sum of squares in SAS:

$$
\begin{aligned}
& \mathrm{DEC}_{\mathrm{s}} \text { or } \mathrm{DEC}_{1 \mathrm{~s}} \text { or } \mathrm{DEC}_{2 \mathrm{~s}}=\text { intercept } \\
& +\sum_{\text {traits }} \alpha_{\text {trait }} \cdot \text { trait value }_{\mathrm{s}}+\gamma \cdot \text { seed persistence index } \mathrm{s}_{\mathrm{s}}+\text { error }
\end{aligned}
$$

Seed traits are dry mass (mg), length, width and height of the seed (mm), the seed shape index (dimensionless), and seed lipid and protein content (\%). $\alpha_{\text {trait }}$ and $\gamma$ are regression coefficients. $\mathrm{DEC}_{1 \mathrm{~s}}$ and $\mathrm{DEC}_{2 \mathrm{~s}}$ were transformed by adding the constant 0.01 to obtain strictly positive values and make the $\log _{\mathrm{n}}$ transformations possible. To account for differences in variance, sum of squares were weighted by the inverse of the seed mortality rate variances. Explanatory variables were kept in the final model if they were significant at $\alpha=0.05$.

In order to account for the phylogenetic relatedness in these comparisons, relationships were also analyzed using phylogenetically independent contrasts (Felsenstein, 1985). This method is based on the comparison of pairs of taxa sharing an immediate common ancestor within a 
phylogeny. A fully resolved tree was built based on the latest phylogeny available (APG III, 2009) and from recent phylogenetic studies at the sub-family level (Kim and Donoghue, 2009; Quintanar et al., 2007). Standardized independent contrasts were calculated as the differences in trait or mortality values (either on raw or log-transformed variables), using Grafen's (1989) branch length estimation method. Multiple linear regressions (manual stepwise backward regressions) were then carried out on the seed mortality contrast as a function of the seed trait contrasts, with the additional constraint of a zero constant (i.e. the regression was forced through the origin, Garland et al. (1992):

$$
\begin{aligned}
& \text { Contrasts of } \mathrm{DEC}_{\mathrm{s}} \text { or } \mathrm{DEC}_{1 \mathrm{~s}} \text { or } \mathrm{DEC}_{2 \mathrm{~s}}= \\
& \sum_{\text {traits }} \alpha_{\text {trait }}^{\prime} \cdot \text { trait contrast }_{\mathrm{s}}+\gamma^{\prime} \cdot \text { seed persistence index contrast } \\
& \mathrm{s}
\end{aligned}
$$

$\alpha_{\text {trait }}^{\prime}$ and $\gamma^{\prime}$ are regression coefficients.

Pairwise correlations within traits and between mortality parameters and traits were also studied, taking into account (or not) phylogenetic relatedness between species. These results are not shown as they did not provide different results from multiple regressions.

\section{Results}

\section{Estimation of seed mortality rates}

For most of the species, the seed recovery rate (number of recovered seeds relative to number of buried seeds) in the seed bags exceeded 95\% (table 1). However, in some species, only $22 \%$ to $64 \%$ of the seeds could be recovered at the end of the experiment (vs. $100 \%$ a few months after burial).

Equations [1] and [2] were fitted with $\mathrm{R}^{2}$ values comprised between 0.23 and 0.96 . During the two years of burial, the overall annual decrease in seed viability ranged from 0.01 $( \pm \mathrm{SE}=0.002)$ or 0.02 ( \pm 0.014$)$, for Echinochloa crus-galli and Fallopia convolvulus, to 0.69 $( \pm 0.040)$ for Digitaria sanguinalis (table 2$)$. During the first year of burial, seed mortality was lower than during the second year in all except one species (Fig. 1, table 2). Once seed viability decreased, marked variability between seed bags was observed at each recovery date (see the standard deviations in Fig. 1). No clear general seasonal pattern could be detected in seed mortality for the studied species at the seed recovery frequency of every two months we used.

The overall seed mortality rate $\mathrm{DEC}_{\mathrm{s}}$ we measured was positively correlated with the seed mortality rates observed in the literature (Fig. 2). However, this result was obtained by excluding Avena fatua and Echinochloa crus-galli from the analysis, as for these species, we measured a lower seed mortality rate than that reported in the literature (table 2). The effect of the presence of soil in the seed bags was not significant, indicating that the addition of soil to the seed bags had no influence on seed mortality in our experiments. Similar results were found for the mortality rates calculated for the first or second year of burial $\left(\mathrm{DEC}_{1 \mathrm{~s}}\right.$ $=1.40 \cdot \mathrm{DEC}_{\text {lit } \mathrm{s}}, \mathrm{R}^{2}=0.69, \mathrm{p}$-value $=8.3 \cdot 10^{-4}, \mathrm{DF}=10 ; \mathrm{DEC}_{2 \mathrm{~s}}=1.54 \cdot \mathrm{DEC}_{\text {lit } \mathrm{s}}, \mathrm{R}^{2}=0.52, \mathrm{p}$ value $\left.=8.5 \cdot 10^{-3}, \mathrm{DF}=10\right)$. The regression parameters exceeded $1(\mathrm{p}$-values $<0.02, \mathrm{DF}=10)$, indicating that the rates measured here were significantly larger than those observed in the literature. 

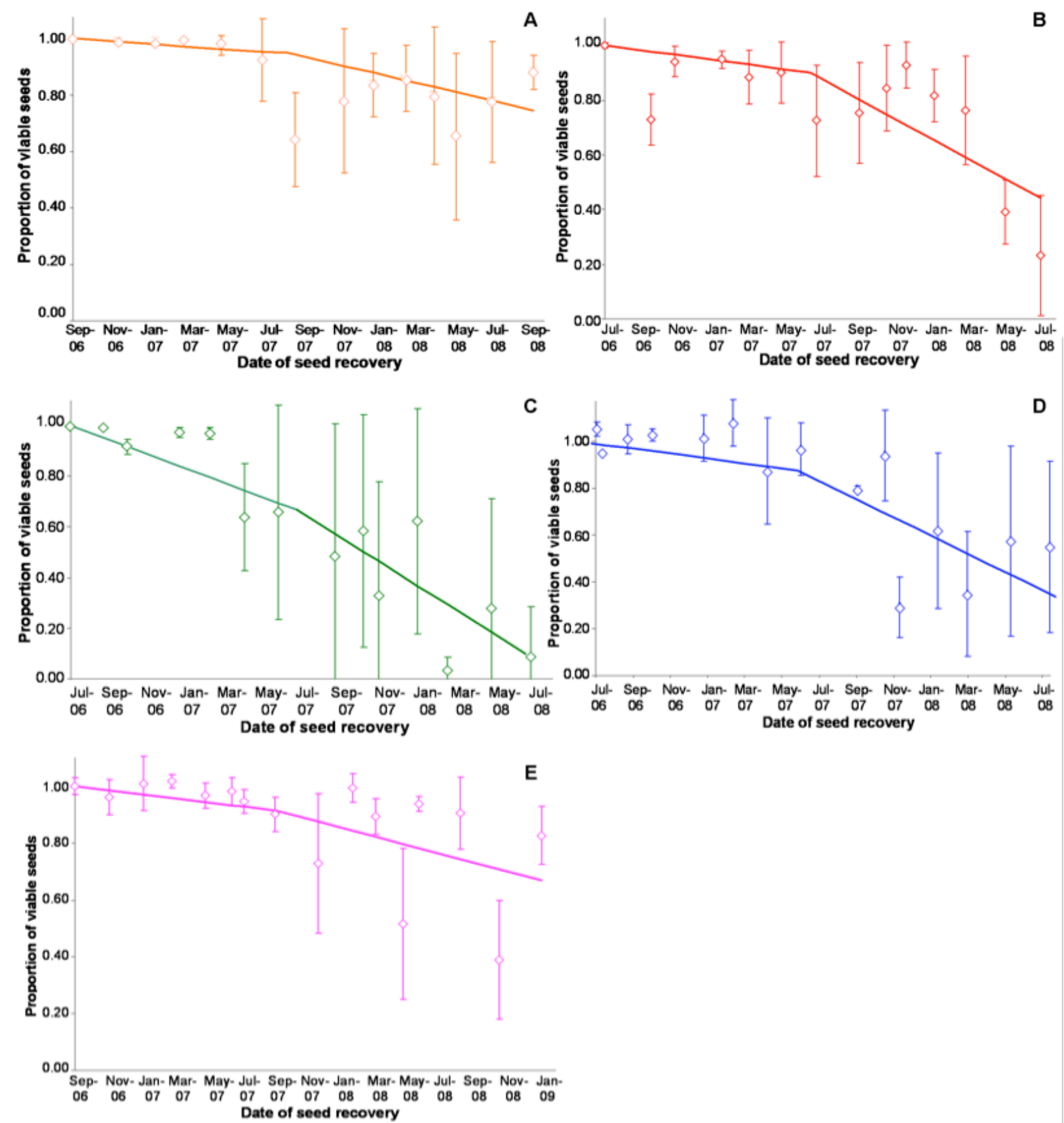

Figure 1. Variation in seed viability ( \pm SD) of Amaranthus hybridus (A), Capsella bursa-pastoris (B), Galium aparine (C), Matricaria perforata (D) and Polygonum lapathifolium (E) during two years of burial in the soil at a depth of $30 \mathrm{~cm}$. The first observation is the initial seed viability measured before burial. Lines are fittings of the broken-stick regression [2]. 
Table 2. Annual in situ seed mortality rates $\left( \pm \mathrm{SE}\right.$, seeds $\left.\cdot \operatorname{seeds}^{-1} \cdot \mathrm{year}^{-1}\right)$ measured during the seed burial experiment compared to seed mortality and persistence data from the literature.

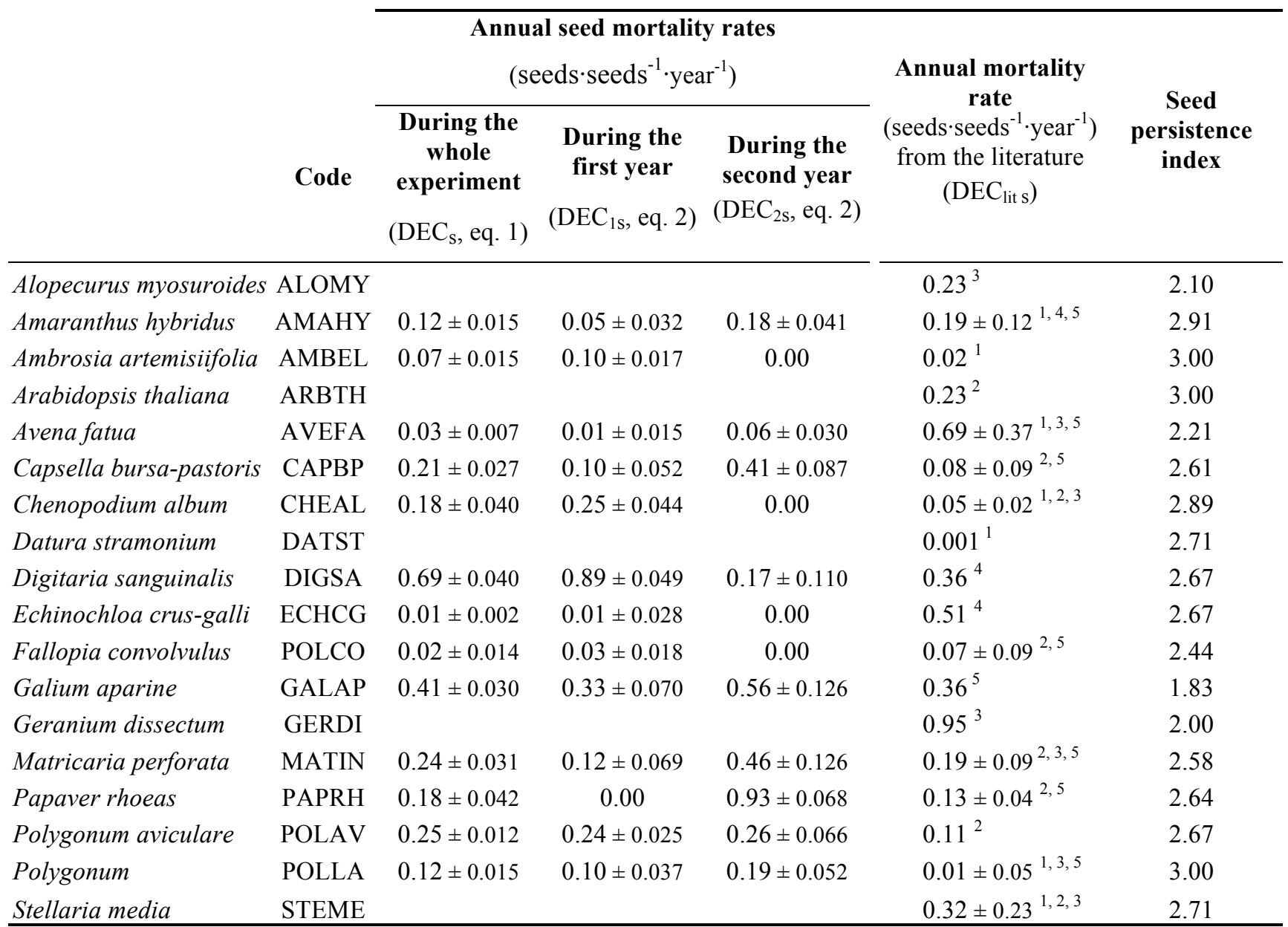

${ }^{1}$ Toole, $1946 ;{ }^{2}$ Roberts and Feast, $1972 ;{ }^{3}$ Lewis, $1973 ;{ }^{4}$ Egley and Chandler, $1983 ;{ }^{5}$ Barralis et al., 1988. 


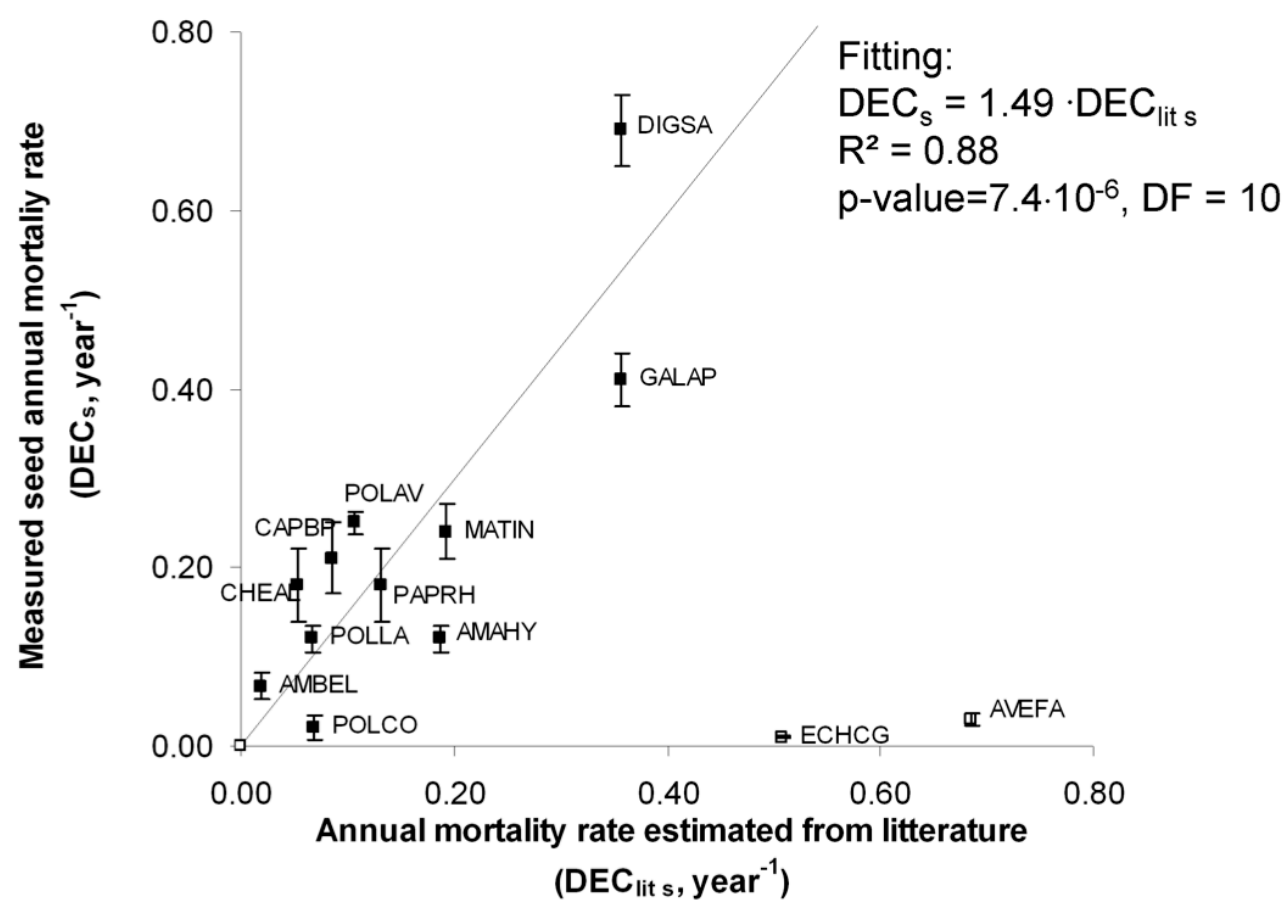

Figure 2. Relationship between the measured seed mortality rate $\left(\mathrm{DEC}_{\mathrm{s}}\right)$ over the two-year burial experiment with a seed depth of $30 \mathrm{~cm}$ and the mortality rate $( \pm \mathrm{SE})$ taken from data in the literature $\left(\mathrm{DEC}_{\text {lit }}\right.$ ). The line shows the fitting of eq. [5]. E. crus-galli and A. fatua were excluded from this regression.

\section{Seed trait values and correlation with seed mortality}

The seed traits varied widely, with seed masses ranging from 0.1 to $18 \mathrm{mg}$ and shapes from spherical to elongated (table 3). Monocotyledonous species (A. myosuroides, A. fatua, D. sanguinalis and E. crus-galli) had low lipid contents ranging from $4 \%$ to $14 \%$, while four dicotyledonous species (A. thaliana, Capsella bursa-pastoris, D. stramonium and Papaver rhoeas) had a seed lipid content exceeding 30\% together with high protein content. The seed coat was the thinnest $(18 \mu \mathrm{m})$ in Digitaria sanguinalis and Capsella bursa-pastoris (Fig. 3). It was ten times thicker in fruits such as the achenes of Ambrosia artemisiifolia $(159 \mu \mathrm{m})$ or Fallopia convolvulus $(230 \mu \mathrm{m})$. The seed persistence index calculated from Thompson et al. (1997) ranged from 1.8 for Galium aparine to 3.0 for Ambrosia artemisiifolia and Polygonum lapathifolium. 
Table 3. Morphological seed traits and seed composition $( \pm$ SD) of the species studied. Seed mass, dimensions and coat thickness were individually measured on 100 seeds while lipid and protein contents were determined on two samples of $250 \mathrm{mg}$ of dry seeds.

\begin{tabular}{|c|c|c|c|c|c|c|c|c|c|}
\hline Species & $\begin{array}{l}\text { Measur } \\
\text { ed } \\
\text { object }\end{array}$ & $\begin{array}{l}\text { Seed coat } \\
\text { thickness } \\
(\mu \mathrm{m})\end{array}$ & $\begin{array}{l}\text { Dry mass } \\
(\mathrm{mg})\end{array}$ & $\begin{array}{l}\text { Length } \\
(\mathrm{mm})\end{array}$ & $\begin{array}{l}\text { Width } \\
(\mathrm{mm})\end{array}$ & $\begin{array}{l}\text { Height } \\
(\mathrm{mm})\end{array}$ & $\begin{array}{l}\text { Seed } \\
\text { shape } \\
\text { index } \\
\end{array}$ & $\begin{array}{l}\text { Lipid content } \\
\left(g \cdot g^{-1}\right)\end{array}$ & $\begin{array}{l}\text { Protein } \\
\text { content } \\
\left(\mathrm{g} \cdot \mathrm{g}^{-1}\right)\end{array}$ \\
\hline $\begin{array}{l}\text { Alopecurus } \\
\text { myosuroides }\end{array}$ & $\begin{array}{l}\text { fruit, } \\
\text { lemma } \\
\text { and } \\
\text { palea }\end{array}$ & $55 \pm 14.5$ & $2.3 \pm 0.67$ & $5.4^{8}$ & $1.7^{8}$ & $0.9^{8}$ & 0.40 & $0.15 \pm 4.6 \cdot 10^{-3}$ & $0.23 \pm 0.3 \cdot 10^{-3}$ \\
\hline $\begin{array}{l}\text { Amaranthus } \\
\text { hybridus }\end{array}$ & fruit & $21 \pm 3.8$ & $0.4 \pm 0.07$ & $1.2^{8}$ & $1.0^{8}$ & $0.7^{8}$ & 0.08 & $0.08 \pm 0.4 \cdot 10^{-3}$ & $0.15 \pm 1.0 \cdot 10^{-3}$ \\
\hline $\begin{array}{l}\text { Ambrosia } \\
\text { artemisiifolia }\end{array}$ & achene & $159 \pm 39.5$ & $4.6 \pm 1.30$ & $4.0 \pm 0.46$ & $2.2 \pm 0.26$ & $1.9^{8}$ & 0.16 & $0.22 \pm 0.8 \cdot 10^{-3}$ & $0.09 \pm 0.0 \cdot 10^{-3}$ \\
\hline $\begin{array}{l}\text { Arabidopsis } \\
\text { thaliana }\end{array}$ & seed & $20 \pm 4.7$ & $0.02^{3}$ & $0.4^{6}$ & $0.4^{6}$ & $0.2^{6}$ & 0.20 & 0.42 & $0.24 \pm 0.5 \cdot 10^{-3}$ \\
\hline Avena fatua & $\begin{array}{l}\text { fruit, } \\
\text { lemma } \\
\text { and palea }\end{array}$ & $129 \pm 18.1$ & $18.5 \pm 6.66$ & $11.3^{4}$ & $2.4^{4}$ & $1.9^{8}$ & 0.44 & $0.09 \pm 1.8 \cdot 10^{-3}$ & $0.08 \pm 0.2 \cdot 10^{-3}$ \\
\hline $\begin{array}{l}\text { Capsella } \\
\text { bursa-pastoris }\end{array}$ & seed & $18 \pm 3.2$ & $0.1 \pm 0.02$ & $1.0^{8}$ & $0.5^{8}$ & $0.3^{8}$ & 0.25 & $0.39 \pm 2.8 \cdot 10^{-3}$ & $0.23 \pm 0.3 \cdot 10^{-3}$ \\
\hline $\begin{array}{l}\text { Chenopodium } \\
\text { album }\end{array}$ & fruit & $72 \pm 12.3$ & 0.56 & $1.4 \pm 0.09$ & $1.3 \pm 0.08$ & $0.7 \pm 0.11$ & 0.13 & $0.09 \pm 0.9 \cdot 10^{-3}$ & $0.14 \pm 1.3 \cdot 10^{-3}$ \\
\hline $\begin{array}{l}\text { Datura } \\
\text { stramonium }\end{array}$ & seed & $133 \pm 39.7$ & $7.2 \pm 1.14$ & $3.5 \pm 0.32$ & $2.9 \pm 0.26$ & $1.4^{6}$ & 0.20 & $0.32 \pm 0.5 \cdot 10^{-3}$ & $0.18^{5,7}$ \\
\hline $\begin{array}{l}\text { Digitaria } \\
\text { sanguinalis }\end{array}$ & $\begin{array}{l}\text { fruit, } \\
\text { lemma, } \\
\text { palea and } \\
\text { glumes }\end{array}$ & $17 \pm 4.0$ & $0.6 \pm 0.09$ & $2.8 \pm 0.24$ & $1.0 \pm 0.08$ & $0.7 \pm 0.10$ & 0.34 & $0.04 \pm 2.8 \cdot 10^{-3}$ & $0.17 \pm 1.3 \cdot 10^{-3}$ \\
\hline $\begin{array}{l}\text { Echinochloa } \\
\text { crus-galli }\end{array}$ & $\begin{array}{l}\text { fruit, } \\
\text { lemma } \\
\text { and palea }\end{array}$ & $92 \pm 17.8$ & $2.2 \pm 0.46$ & $3.9 \pm 0.67$ & $1.9 \pm 0.26$ & $0.9^{8}$ & 0.30 & $0.06 \pm 1.2 \cdot 10^{-3}$ & $0.13 \pm 0.8 \cdot 10^{-3}$ \\
\hline $\begin{array}{l}\text { Fallopia } \\
\text { convolvulus }\end{array}$ & achene & $230 \pm 44.2$ & $6.5 \pm 1.39$ & $4.3 \pm 0.23$ & $2.7 \pm 0.18$ & $2.5^{8}$ & 0.10 & $0.03 \pm 1.0 \cdot 10^{-3}$ & $0.15 \pm 0.5 \cdot 10^{-3}$ \\
\hline $\begin{array}{l}\text { Galium } \\
\text { aparine }\end{array}$ & mericarp & $31 \pm 8.6$ & $7.4 \pm 2.39$ & $2.7 \pm 0.45$ & $2.5 \pm 0.41$ & $1.8 \pm 0.30$ & 0.06 & $0.04 \pm 0.8 \cdot 10^{-3}$ & $0.11 \pm 0.8 \cdot 10^{-3}$ \\
\hline $\begin{array}{l}\text { Geranium } \\
\text { dissectum }\end{array}$ & seed & $21 \pm 3.9$ & $2.1 \pm 0.36$ & $2.0 \pm 0.11$ & $1.4 \pm 0.09$ & $1.4 \pm 0.00$ & 0.05 & $0.21 \pm 8.0 \cdot 10^{-3}$ & $0.24 \pm 1.3 \cdot 10^{-3}$ \\
\hline $\begin{array}{l}\text { Matricaria } \\
\text { perforata }\end{array}$ & achene & $24 \pm 80.0$ & $0.3 \pm 0.08$ & $2.0^{8}$ & $0.7^{8}$ & $0.5^{8}$ & 0.33 & $0.19 \pm 1.3 \cdot 10^{-3}$ & $0.15 \pm 0.0 \cdot 10^{-3}$ \\
\hline $\begin{array}{l}\text { Papaver } \\
\text { rhoeas }\end{array}$ & seed & $30 \pm 7.6$ & 0.11 & $0.8^{8}$ & $0.5^{8}$ & $0.5^{8}$ & 0.08 & $0.44 \pm 2.4 \cdot 10^{-3}$ & $0.23 \pm 0.3 \cdot 10^{-3}$ \\
\hline $\begin{array}{l}\text { Polygonum } \\
\text { aviculare }\end{array}$ & achene & $74 \pm 18.0$ & $1.5 \pm 0.59$ & $2.9 \pm 0.55$ & $1.6 \pm 0.20$ & $1.6 \pm 0.18$ & 0.13 & $0.04 \pm 2.8 \cdot 10^{-3}$ & $0.12 \pm 0.3 \cdot 10^{-3}$ \\
\hline $\begin{array}{l}\text { Polygonum } \\
\text { lapathifolium }\end{array}$ & achene & $102 \pm 21.7$ & $2.0 \pm 0.58$ & $2.7^{4}$ & $2.3^{4}$ & $1.0^{4}$ & 0.22 & $0.05 \pm 0.1 \cdot 10^{-3}$ & $0.11 \pm 0.1 \cdot 10^{-3}$ \\
\hline $\begin{array}{l}\text { Stellaria } \\
\text { media }\end{array}$ & seed & $27 \pm 4.7$ & 0.40 & $1.0 \pm 0.07$ & $0.9 \pm 0.07$ & $0.56^{2}$ & 0.11 & $0.06^{1}$ & $0.18^{2,7}$ \\
\hline
\end{tabular}

Origin of traits taken from the literature: ${ }^{1}$ (Aitzetmüller et al., 2003); ${ }^{2}$ (Barclay and Earle, 1974); ${ }^{3}$ (Flynn et al., 2006);

${ }^{4}$ (Holm-Nielsen, 1998); ${ }^{5}$ (Jones and Earle, 1966); ${ }^{6}$ (Kühn et al., 2004); ${ }^{7}$ (Schroeder et al., 1974); ${ }^{8}$ (Sevic, 2003). 


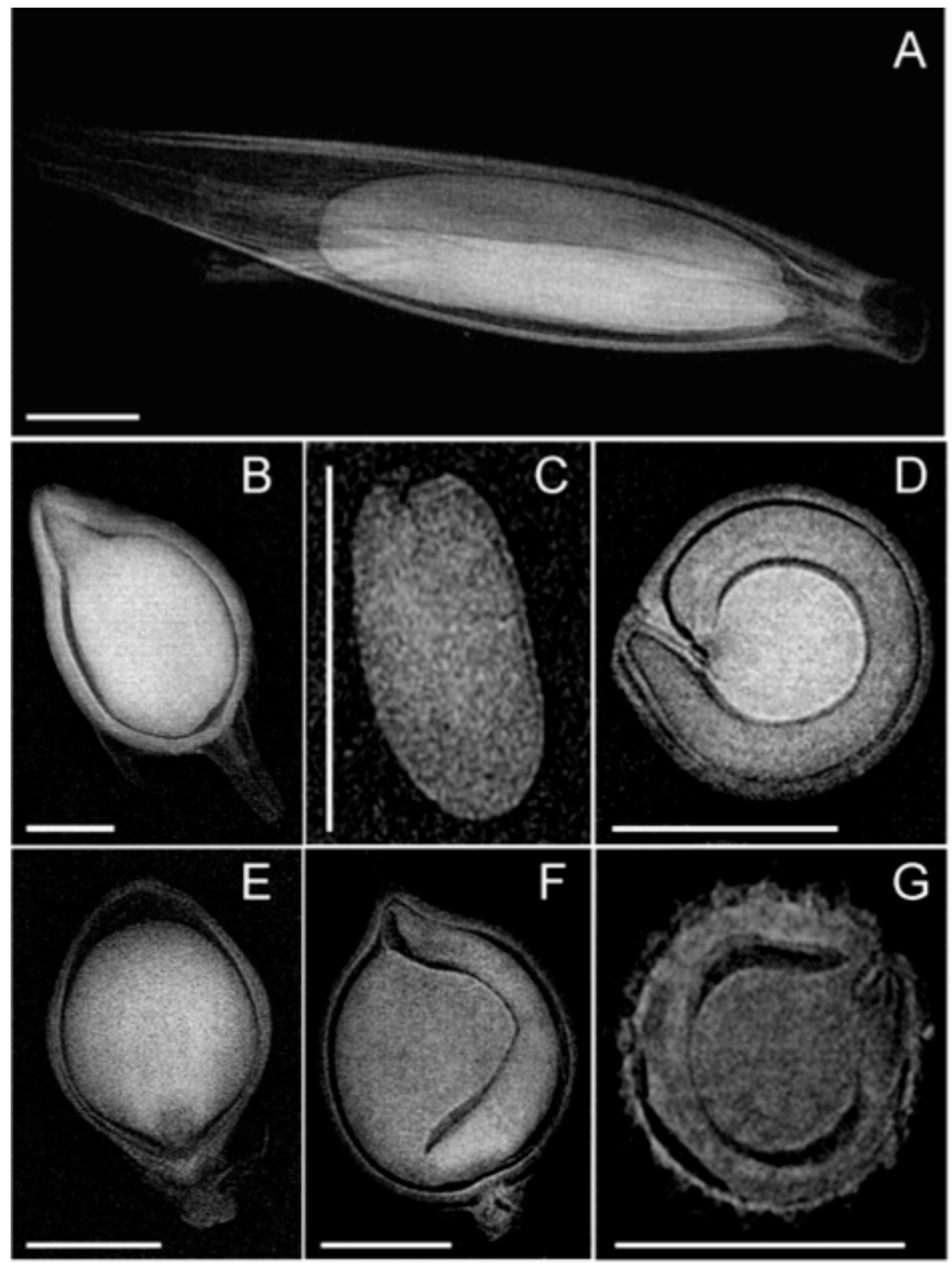

Figure 3. X-ray images of seeds of nine weed species with contrasted seed coat thickness. A: Avena fatua; B: Ambrosia artemisiifolia; C: Capsella bursa-pastoris; D: Chenopodium album; E: Echinochloa crus-galli; F: Polygonum lapathifolium; G: Stellaria media. White bars represent $1 \mathrm{~mm}$. 
The seed mortality rates decreased hyperbolically with seed coat thickness (Fig. 4). The relationship was significant whatever the period of time for which mortality rates were calculated, seed coat thickness explaining as much as $62 \%$ of the between-species variability during the second year (table 4). These negative correlations remained significant when controlling for phylogenetic relatedness, with $\mathrm{R}^{2}$ comprised between 0.37 and 0.81 (Fig. 5). The seed mortality rates were not significantly correlated with other seed morphological traits, or with either seed reserves or the seed persistence index, whether the effects of phylogeny were considered or not.

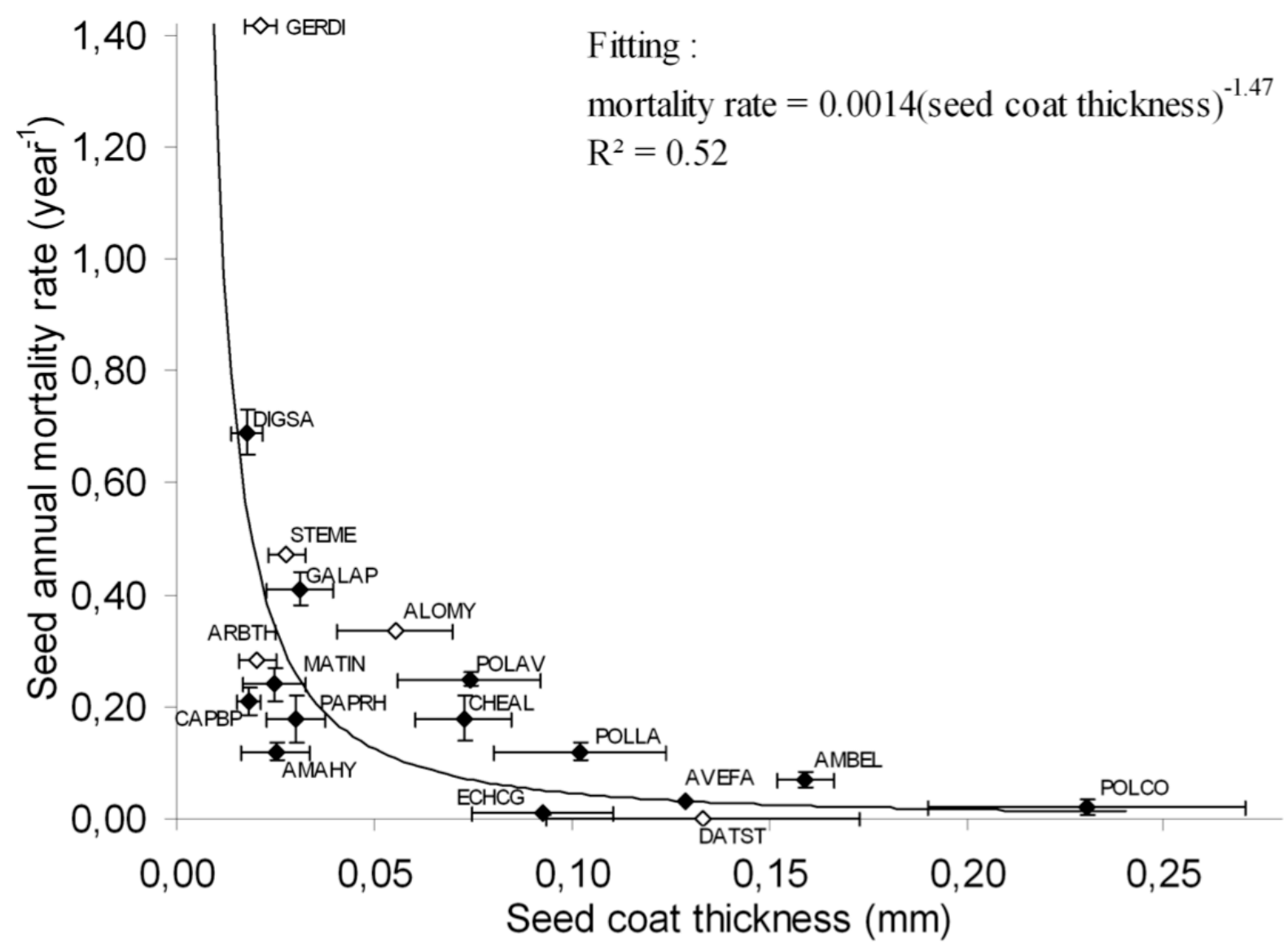

Figure 4. Annual seed mortality rate $\left(\mathrm{DEC}_{\mathrm{s}}, \pm \mathrm{SE}\right)$ in the soil as a function of seed coat thickness $( \pm$ SD). Results of a two-year burial experiments with seeds recovered from a depth of $30 \mathrm{~cm}(\diamond)$ and data from the literature $(\diamond)$. The line shows the fitting of equation [6]. A mortality rate exceeding 1 means that all the seeds lost their viability in less than one year. 
Table 4. Effects of species traits on seed mortality measured in the present burial experiment (13 species) or estimated from the literature (4 additional species).

\begin{tabular}{|c|c|c|c|c|c|}
\hline \multirow{2}{*}{$\begin{array}{l}\text { Predicted variables } \\
\left(\log _{n} \text {-transformed }\right)\end{array}$} & \multicolumn{2}{|c|}{$\begin{array}{l}\text { Regression parameters } \\
\quad\left(\log _{\mathrm{n}} \text {-transformed }\right)\end{array}$} & \multirow[b]{2}{*}{ DF } & \multirow[b]{2}{*}{$\mathbf{R}^{2}$} & \multirow[b]{2}{*}{$\begin{array}{l}\text { p-value of } \\
\text { the model }\end{array}$} \\
\hline & Intercept & $\begin{array}{c}\text { Seed coat } \\
\text { thickness }(\mathrm{mm})\end{array}$ & & & \\
\hline $\begin{array}{l}\text { Mortality rate during the first } \\
\text { year after burial }\left(\mathrm{DEC}_{1 \mathrm{~s}} \text {, year- }\right. \\
\left.{ }^{1}\right)\end{array}$ & $-4.63 \pm 1.08$ & $-0.80 \pm 0.36$ & 17 & 0.24 & $4.1 \cdot 10^{-2}$ \\
\hline $\begin{array}{l}\text { Mortality rate during the } \\
\text { second year after burial } \\
\left(\mathrm{DEC}_{2 \mathrm{~s}}, \text { year }^{-1}\right)\end{array}$ & $-7.23 \pm 0.97$ & $-1.67 \pm 0.34$ & $16^{*}$ & 0.62 & $2.0 \cdot 10^{-4}$ \\
\hline $\begin{array}{l}\text { Mortality rate during the two } \\
\text { years of burial }\left(\mathrm{DEC}_{\mathrm{s}} \text {, year } \text { year }^{-1}\right)\end{array}$ & $-6.56 \pm 1.10$ & $-1.47 \pm 0.37$ & 17 & 0.52 & $1.0 \cdot 10^{-3}$ \\
\hline
\end{tabular}

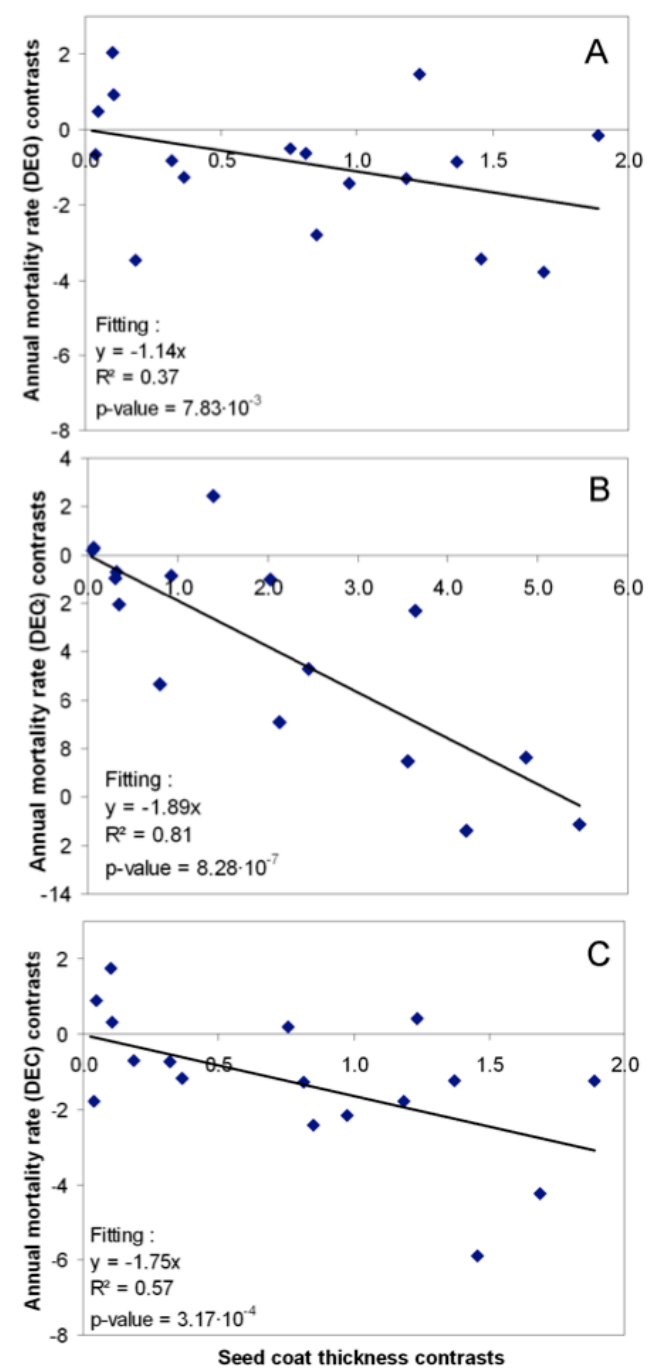

Figure 5. Relationships between seed coat thickness contrasts and mortality rate contrasts during the first year (A), second year (B) or during the whole period of burial (C). Contrasts were calculated on log-transformed data. The line shows the fitting of equation [7]. 


\section{Discussion}

During the first year of burial, seed viability only decreased slightly in most of the studied species, even in non-dormant species such as Matricaria perforata (Woo et al., 1991). Seed losses due to germination could therefore be considered as negligible in the present experiment, and the mortality observed during the second year mostly resulted from parasite attacks or seed aging. The higher mortality rates during the second year may be explained by the lag time necessary for the seed teguments to soften or to lose their toxic compounds, or for seed pathogens to develop sufficiently to cause serious seed losses. Marked differences appeared in seed viability among species after two years in the soil. For instance, more than $75 \%$ of the seeds of Galium aparine or Digitaria sanguinalis disappeared whereas more than $80 \%$ of Amaranthus hybridus or Polygonum lapathifolium seeds were still viable. For the latter species, tillage prior to crop sowing should be chosen carefully to create conditions that are unfavourable for germination (i.e. bury seeds, till when seeds are dormant, etc. as long as their seeds are viable. Species with short-term viability will only persist in fields with frequent favourable crops where they emerge and reproduce best. Poorly diversified and no-till cropping systems will enable even weeds with high mortality rates to reproduce each year, resulting in large populations.

For most of the studied species, the seed mortality rates measured in our experiment were consistent with those observed in the literature. However, the mortality rates we measured were systematically higher than those found in the literature. The latter were obtained in seed burial conditions that differed from those in our study by their soil climate and texture, which may have an effect on seed in situ mortality. Conversely, the mortality rates measured in our study for Echinochloa crus-galli and Avena fatua were lower than those reported in the literature (0.01 vs. 0.51 from Barralis et al., 1988; 0.03 vs. 0.69 from Egley and Chandler, 1983; Lewis, 1973; Toole and Brown, 1946). The higher mortality rates reported in the literature for these two weeds could be explained by differences in the protocols. For instance, seeds were usually buried less deeply in studies in the literature, and seed germination was thus not completely inhibited. This point illustrates the difficulty we had in finding studies suited to our objective (i.e. assessing seed mortality independently of seed losses by germination) and using similar seed burial protocols.

In the present experiment, the seed mortality rate was computed with a linear regression for two successive one-year periods. It would have been useful to extend our seed burial experiment beyond two years, especially for seeds with low mortality rates, and to fit a single sigmoidal model to data as in other studies (e.g. Masin et al., 2006) where each species was characterized by its half-viability period. On the other hand, we were able to analyze a large number of contrasted species and to relate the observed seed mortality rate with easily measured seed traits. Indeed, seed coat thickness (which varied more than ten-fold in the studied species) was negatively correlated with seed mortality in the soil during the two years of our burial experiment, whether phylogenetic relatedness was included or not. This relationship explained half the variability in mortality rates. This seed trait has rarely been measured in spite of its assumed importance in several processes in seed bank dynamics (seed dormancy, predation or persistence). Very few data are available in the literature as, until recently, no techniques were available to measure this trait rapidly on a large number of species. Now, improved technology is available, e.g. X-ray images, which proved to be very efficient for such measurements. For very thin seed coats, however, the precision of the measurements was affected by a low resolution of the images.

The present results confirm, for a larger number of species, those of Davis et al. (2008) who found an analogous relationship between seed coat thickness and the time to half mortality in 
five American weed species. A thick seed coat can be provide efficient protection for the seed embryo against external aggressions caused by microorganisms and other abiotic factors such as temperature and moisture variations. However, the present study shows that seed coat thickness only explains approximately two thirds of the variability in seed mortality. Seeds may present natural permeability sites or other structural features (e.g. the strophiole) that enhance seed permeability (Kelly et al., 1992). Moreover, other traits of the seed coat could influence seed mortality, such as seed surface characteristics (e.g. smooth vs. rough) creating microsites favouring the colonization of the seed by microorganisms (Chee-Sanford et al., 2006). Conversely, chemical compounds such as phenols may protect seeds from fungal or bacterial attacks (Hendry et al., 1994). However, considering the costs of these protection mechanisms, a trade-off can be expected between them. Indeed, a negative relationship was reported between seed coat thickness and seed phenol content, the former playing a primary role in preserving seed integrity, the latter having only a complementary effect (Davis et al., 2008).

The remaining unexplained variability in seed mortality was not significantly correlated with seed lipid or protein contents, which is consistent with reports in the literature (Priestley et al., 1985). The total protein and oil contents might, however, not be sufficiently precise to identify the seed's ability to survive over the years. Proteins that are used as markers of seed lot conservation ability could be better predictors for seed mortality (Oge et al., 2008; Rajjou et al., 2008). However, these chemical characteristics cannot be easily identified and measured in a wide range of species.

Seed mortality in the soil was not correlated with seed mass and shape, in contrast to the results of prior studies on seed persistence (Cerabolini et al., 2003). In these studies, the most persistent seeds were small and spherical. These seeds may migrate easily to deeper soil layers where germination is inhibited, thus reducing seed loss through germination and increasing persistence (Bekker et al., 1998). This was not the case in our experimental conditions (where seed burial was fixed) or in most fields where seeds are buried by tillage, irrespective of their morphology (Moss, 1988). Saatkamp et al (2009) also failed to find a relationship between seed survival measured in their burial experiments and seed persistence in the literature. This is consistent with results of the present experiment, where seed mortality and seed persistence were not correlated either.

The weed flora present in a particular field are the result of several elements of cropping systems interacting with the seed bank. The present equations for predicting seed mortality in the soil therefore need to be integrated into comprehensive weed dynamics models that account for the remaining life-cycle processes and relate model parameters to species traits. We already succeeded in relating pre-emergence growth parameters to seed mass (Gardarin et $a l ., 2010)$ and are still working on germination and dormancy parameters. Seed dormancy might also be explained by seed coat properties (Baskin and Baskin, 1998), which could result in a correlation between mortality and dormancy. A relationship between these two processes is also expected as there is no advantage in being dormant and avoiding early germination if the seeds do not survive to germinate in later seasons. Many other crucial processes such as seed predation still remain to be modelled at the interspecific level. These multi-specific weed dynamics models will be used to evaluate different crop management techniques, such as burying the seeds by mouldboard ploughing to prevent the emergence of the most unwanted weeds, in interaction with the characteristics of each species. 


\section{Acknowledgements}

The present work was financed by INRA (Département Environnement et Agronomie), ANR OGM VIGIWEED (ANR-07-POGM-003-01) and the Region of Burgundy. The authors are grateful to the INRA experimental station of Dijon-Époisses for providing the experimental site for the seed burial, to Christophe Salon and Anne-Lise Santoni (INRA, UMR LEG) as well as Lionel Bretillon and Stéphane Grégoire (INRA, UMR FLAVIC) for analyses of the seed reserves, to the Station Nationale d'Essais des Semences (SNES), to Laurence Le Corre for the seed coat X-ray images and to two anonymous reviewers for their helpful comments. 


\section{References}

Aitzetmüller, K., Matthaüs, B. and Friedrich, H. (2003) A new database for seed oil fatty acids - the database SOFA. European Journal of Lipid Science and Technology 105, 92-103.

APG III (2009) An update of the Angiosperm Phylogeny Group classification for the orders and families of flowering plants: APG III. Botanical Journal of the Linnean Society 161, 105121.

Barclay, A.S. and Earle, F.R. (1974) Chemical analyses of seeds. III. Oil and protein content of 1253 species. Economic Botany 28, 178-236.

Barralis, G., Chadoeuf, R. and Lonchamp, J. (1988) Longévité des semences de mauvaises herbes annuelles dans un sol cultivé. Weed Research 28, 407-418.

Baskin, C.C. and Baskin, J.M. (1998) Seeds: ecology, biogeography, and evolution of dormancy and germination. San Diego, USA, Academic Press.

Bekker, R.M., Bakker, J.P., Grandin, U., Kalamees, R., Milberg, P., Poschlod, P., Thompson, K. and Willems, J.H. (1998) Seed size, shape and vertical distribution in the soil: indicators of seed longevity. Functional Ecology 12, 834-842.

Boyd, N.S. and Van Acker, R.C. (2003) The effects of depth and fluctuating soil moisture on the emergence of eight annual and six perennial plant species. Weed Science 51, 725-730.

Burnside, O.C., Wilson, R.G., Weisberg, S. and Hubbard, K.G. (1996) Seed longevity of 41 weed species buried 17 years in eastern and western Nebraska. Weed Science 44, 74-86.

Cerabolini, B., Ceriani, R.M., Caccianiga, M., Andreis, R.d. and Raimondi, B. (2003) Seed size, shape and persistence in soil: a test on Italian flora from Alps to Mediterranean coasts. Seed Science Research 13, 75-85.

Chee-Sanford, J.C., Williams, M.M., II, Davis, A.S. and Sims, G.K. (2006) Do microorganisms influence seed-bank dynamics? Weed Science 54, 575-587.

Clements, D.R., Weise, S.F. and Swanton, C.J. (1994) Integrated weed management and weed species diversity. Phytoprotection 75, 1-18.

Colbach, N., Chauvel, B., Gauvrit, C. and Munier-Jolain, N.M. (2007) Construction and evaluation of ALOMYSYS modelling the effects of cropping systems on the blackgrass lifecycle: From seedling to seed production. Ecological Modelling 201, 283-300.

Conn, J.S., Beattie, K.L. and Blanchard, A. (2006) Seed viability and dormancy of 17 weed species after 19.7 years of burial in Alaska. Weed Science 54, 464-470.

Corbineau, F., Gay-Mathieu, C., Vinel, D. and Come, D. (2002) Decrease in sunflower (Helianthus annuus) seed viability caused by high temperature as related to energy metabolism, membrane damage and lipid composition. Physiologia Plantarum 116, 489-496.

Davis, A.S., Schutte, B.J., Iannuzzi, J. and Renner, K.A. (2008) Chemical and physical defense of weed seeds in relation to soil seedbank persistence. Weed Science 56, 676-684.

Earle, F.R. and Jones, Q. (1962) Analyses of seed samples form 113 plant families. Economic Botany 16, 211-250.

Egley, G.H. and Chandler, J.M. (1983) Longevity of weed seeds after 5.5 years in the Stoneville 50-year buried-seed study. Weed Science 31, 264-270.

Egley, G.H. and Williams, R.D. (1990) Decline of weed seeds and seedling emergence over five years as affected by soil disturbances. Weed Science 38, 504-510. 
Felsenstein, J. (1985) Phylogenies and the comparative method. The American Naturalist 125,1 .

Flynn, S., Turner, R.M. and Stuppy, W.H. (2006) Seed Information Database (release 7.0, October 2006), http://www.kew.org/data/sid.

Gardarin, A., Dürr, C. and Colbach, N. (2010) Effects of seed depth and soil structure on the emergence of weeds with contrasted seed traits. Weed Research 50, 91-101.

Garland, T., Jr., Harvey, P.H. and Ives, A.R. (1992) Procedures for the analysis of comparative data using phylogenetically independent contrasts. Systematic Biology 41, 18-32.

Grafen, A. (1989) The phylogenetic regression. Philosophical Transactions of the Royal Society of London. B, Biological Sciences 326, 119-157.

Hansen, B. (1989) Determination of nitrogen as elementary N, an alternative to Kjeldhal. Acta Agriculturae Scandinavica 39, 113-118.

Hendry, G.A.F., Thompson, K., Moss, C.J., Edwards, E. and Thorpe, P.C. (1994) Seed persistence: a correlation between seed longevity in the soil and ortho-dihydroxyphenol concentration. Functional Ecology 8, 658-664.

Holm-Nielsen, C. (1998) Frø fra det dyrkede land. Flakkebjerg, Danemark., Ministeriet for Fødevarer, Landbrug og Frikeri, Danmarks JordbrugsForskning.

Holst, N., Rasmussen, I.A. and Bastiaans, L. (2007) Field weed population dynamics: a review of model approaches and applications. Weed Research 47, 1-14.

Hulme, P.E. (1998) Post-dispersal seed predation: consequences for plant demography and evolution. Perspectives in Plant Ecology, Evolution and Systematics 1, 32-46.

Jensen, S., Johnels, A.G., Olsson, M. and Otterlind, G. (1972) DDT and PCB in herring and cod from the Baltic, the Kattegat and the Skagerrak. Ambio Special Report No 1 1, 71-85.

Jones, Q. and Earle, F.R. (1966) Chemical analyses of seeds II: Oil and protein content of 759 species. Economic Botany 20, 127-155.

Keddy, P.A. (1992) A pragmatic approach to functional ecology. Functional Ecology 6, 621626.

Kelly, K.M., Staden, J.v. and Bell, W.E. (1992) Seed coat structure and dormancy. Plant Growth Regulation 11, 201-209.

Kerguélen, M. and Bock, B. (2009) Base de données nomenclaturale de la flore de France, Tela Botanica, www.tela-botanica.org. Visited in 2009.

Kim, S.-T. and Donoghue, M.J. (2009) Molecular phylogeny of Persicaria (Persicarieae, Polygonaceae). Systematic Botany 33, 77-86.

Kühn, I., Durka, W. and Klotz, S. (2004) BiolFlor - a new plant-trait database as a tool for plant invasion ecology. Diversity and Distributions 10, 363-365.

Lewis, J. (1973) Longevity of crop and weed seeds: survival after 20 years in soil. Weed Research 13, 179-191.

Lonchamp, J.P. and Gora, M. (1980) Évolution de la faculté germinative de semences de mauvaises herbes au cours de leur conservation au sec. Rapport interne INRA Malherbologie.

Majumdar, J.D.S. and Jayas, D. (2000) Classification of cereal grains using machine vision. I. Morphological models. American Society of Agricultural Engineers 43, 1669-1675. 
Mariotti, F., Tome, D. and Mirand, P.P. (2008) Converting nitrogen into protein - Beyond 6.25 and Jones' factors. Critical Reviews in Food Science and Nutrition 48, 177-184.

Masin, R., Zuin, M.C., Otto, S. and Zanin, G. (2006) Seed longevity and dormancy of four summer annual grass weeds in turf. Weed Research 46, 362-370.

Mohamed-Yasseen, Y., Barringer, S.A., Splittstoesser, W.E. and Costanza, S. (1994) The role of seed coats in seed viability. Botanical Review 60, 426-439.

Montégut, J. (1975) Ecologie de la germination des semences. p 231 in Chaussatet, R. and Deunff., Y.1. (Eds) La Germination des Semences. Paris, France, Bordas.

Moss, S.R. (1988) Influence of cultivations on the vertical distribution of weed seeds in the soil. pp 71-80 VIIIe colloque international sur la biologie, l'écologie et la systematique des mauvaises herbes. Dijon.

Muracciole, V., Plainchault, P., Bertrand, D. and Mannino, M.R. (2007) Development of an automated device for sorting seeds - application on sunflower seeds. ICINCO-RA (1), 311318.

Murdoch, A.J. and Ellis, R.H. (2000) Dormancy, viability and longevity. pp 183-214 Seeds: the ecology of regeneration in plant communities. Wallingford UK, Cabi.

Oge, L., Bourdais, G., Bove, J., Collet, B., Godin, B., Granier, F., Boutin, J.P., Job, D., Jullien, M. and Grappin, P. (2008) Protein repair L-isoaspartyl methyltransferase1 is involved in both seed longevity and germination vigor in Arabidopsis. Plant Cell 20, 30223037.

Ponquett, R.T., Smith, M.T. and Ross, G. (1992) Lipid autoxidation and seed ageing: putative relationships between seed longevity and lipid stability. Seed Science Research 2, 5154.

Priestley, D.A. (1986) Seed Aging - Implications for seed storage and persistence in the soil. p 304, Comstock publishing associates.

Priestley, D.A., Cullinan, V.I. and Wolfe, J. (1985) Differences in seed longevity at the species level. Plant, Cell and Environment 8, 557-562.

Quintanar, A., Castroviejo, S. and Catalan, P. (2007) Phylogeny of the tribe Aveneae (Pooideae, Poaceae) inferred from plastid trnT-F and nuclear ITS sequences. Am. J. Bot. 94, 1554-1569.

Rajjou, L., Lovigny, Y., Groot, S.P.C., Belghaz, M., Job, C. and Job, D. (2008) Proteomewide characterization of seed aging in Arabidopsis: A comparison between artificial and natural aging protocols. Plant Physiology 148, 620-641.

Rasband, W.S. (2009) ImageJ, U. S. National Institutes of Health. Bethesda, Maryland, USA, http://rsb.info.nih.gov/ij/, 1997-2009.

Roberts, H.A. and Boddrell, J.E. (1983) Seed survival and periodicity of seedling emergence in ten species of annual weeds. Annals of Applied Biology 102, 523-532.

Roberts, H.A. and Feast, P.M. (1972) Fate of seeds of some annual weeds in different depths of cultivated and undisturbed soil. Weed Research 12, 316-324.

Saatkamp, A., Affre, L., Dutoit, T. and Poschlod, P. (2009) The seed bank longevity index revisited: limited reliability evident from a burial experiment and database analyses. Annals of Botany 104, 715-724. 
Sawma, J.T. and Mohler, C.L. (2002) Evaluating seed viability by an unimbibed seed crush test in comparison with the tetrazolium test. Weed Technology 16, 781-786.

Schroeder, M., Deli, J., Schall, E.D. and Warren, G.F. (1974) Seed composition of 66 weed and crop species. Weed Science 22, 345-348.

Sester, M., Dürr, C., Darmency, H. and Colbach, N. (2006) Evolution of weed beet (Beta vulgaris L.) seed bank: quantification of seed survival, dormancy, germination and preemergence growth. European Journal of Agronomy 24, 19-25.

Sevic, A. (2003) Relations entre taille, forme des semences de mauvaises herbes et leur longévité dans le sol. p 19, Rapport de stage de maîtrise, INRA, Dijon, 19p.

Thompson, K., Bakker, J.P. and Bekker, R.M. (1997) The soil seed banks of north west Europe: methodology, density and longevity. Cambridge UK, Cambridge University Press.

Thompson, K., Band, S.R. and Hodgson, J.G. (1993) Seed size and shape predict persistence in soil. Functional Ecology 7, 236-241.

Toole, E.H. and Brown, E. (1946) Final results of the duvel buried seed experiment. Journal of Agricultural Research 72, 201-210.

Violle, C., Navas, M.L., Vile, D., Kazakou, E., Fortunel, C., Hummel, I. and Garnier, E. (2007) Let the concept of trait be functional! Oikos 116, 882-892.

Wagner, M. and Mitschunas, N. (2008) Fungal effects on seed bank persistence and potential applications in weed biocontrol: A review. Basic and applied ecology 9, 191-203.

Webster, R.H. (1979) Growing weeds from seeds and other propagules for experimental purposes. p 21 Technical Report, Agricultural Research Council Weed Research Organization.

Weiher, E., Werf, A.v.d., Thompson, K., Roderick, M., Garnier, E. and Eriksson, O. (1999) Challenging Theophrastus: a common core list of plant traits for functional ecology. Journal of Vegetation Science 10, 609-620.

Westerman, P.R., Liebman, M., Heggenstaller, A.H. and Forcella, F. (2006) Integrating measurements of seed availability and removal to estimate weed seed losses due to predation. Weed Science 54, 566-574.

Woo, S.L., Thomas, A.G., Peschken, D.P., Bowes, G.G., Douglas, D.W., Harms, V.L. and McClay, A.S. (1991) The biology of Canadian weeds. 99. Matricaria perforata Merat (Asteraceae). Canadian Journal of Plant Science 71, 1101-1119. 